\title{
Low Levels of Complement Factor C4 Not Always Implicate Disease Activity in Systemic Lupus Erythematosus
}

\author{
E. J. ter Borg ${ }^{1}$, H. van Velzen-Blad ${ }^{2}$, D. Hamann ${ }^{3}$ \\ ${ }^{1}$ Department of Internal Medicine and Rheumatology, St. Antonius Hospital Nieuwegein/Utrecht, Nieuwegein, The Netherlands; \\ ${ }^{2}$ Department of Clinical Immunology, St. Antonius Hospital Nieuwegein/Utrecht, Nieuwegein, The Netherlands; ${ }^{3}$ Department of \\ Immunopathology and Blood Coagulation, Sanquin Diagnostics, Amsterdam, The Netherlands. \\ Email: borg@antoniusziekenhuis.nl,h.vvelzen@ antoniusziekenhuis.nl, d.hamann@sanquin.nl
}

Received October $21^{\text {st }}, 2012$; revised November $22^{\text {nd }}, 2012$; accepted November $30^{\text {th }}, 2012$

\begin{abstract}
A lupus patient with a clinically quiescent disease stage will be described who had severely depressed C4 levels while levels of $\mathrm{C} 3$ en CH50 were normal. Additional testing revealed a homozygous C4A isotype deficiency as the cause of the very low C4 levels. It should be emphasized that in SLE, a (very) low C4 level does not always means (subclinical) disease activity.
\end{abstract}

Keywords: Complement; Homozygous C4A Isotype Deficiency; Systemic Lupus Erythematosus

\section{Introduction}

Disease activity in systemic lupus erythematosus usually is monitored by serially measurements of anti-dsDNA [1] and C3/4 levels [1-3]. When levels of C3 and/or C4 fall, the clinician has to be extra alert for a flare up of disease. Complement factor $\mathrm{C} 4$ exists as two main isotypes: $\mathrm{C} 4 \mathrm{~A}$ and C4B, encoded by two closely linked genes. The C4 gene copy number varies from 2 - 6, but it is mostly 4 [4].

Inherited deficiencies of complement components C14 are associated in nearly 50\% with SLE [5]. Partial C4 deficiency has been associated with SLE, the most common being C4A deficiency $[5,6]$ and susceptibility to bacterial infection (C4B, [7]). In lupus, the prevalence of homozygous C4A deficiency has been reported between $10.2 \%-22.2 \%$ in white patients [5]. Homozygous deficiency of C4A has been reported to occur in $5.8 \%$ in healthy lab workers [8].

It has been postulated that C4A deficiency leads to impaired clearance of immune complexes, explaining its association with immune complex diseases [5].

\section{Case}

A 45-year-old female was admitted because of a symmetric rheumatoid-factor negative polyarthritis, treated by diclofenac by the general practitioner. Her previous history included a hysterectomy, lumbar hernia nuclei pulposi and a depression one year before admission.
Since one month she experienced generalized joint pains with morning stiffness. Physical examination showed polyarthritis with fever up to $38.5^{\circ}$ Celsius, cervical lymphadenopathy and a rash. Her admission was complicated by a short period of atrial fibrillation. Laboratory findings (see Table 1): ESR $90 \mathrm{~mm} /$ first hour, CRP at maximum $42 \mathrm{mg} / \mathrm{l}$ (normal $<5 \mathrm{mg} / \mathrm{l}$ ), normal blood counts, WBC-differentiation and renal function. Transaminases were disturbed probably by the use of diclofenac: ASAT $325 \mathrm{IU} / \mathrm{L}$, ALAT $500 \mathrm{IU} / \mathrm{L}$ with normal values for AF, GGT and CPK. Urine analysis showed slight proteinuria $(600 \mathrm{mg} / \mathrm{l})$ with a normal sediment. ANA were

Table 1. Some laboratory examinations at admission.

\begin{tabular}{ccc}
\hline Item & Measured value & Normal value \\
\hline ESR & $90 \mathrm{~mm} /$ first hour & $<12 \mathrm{~mm} /$ first hour \\
CRP & $42 \mathrm{mg} / \mathrm{l}$ & $<5 \mathrm{mg} / \mathrm{l}$ \\
ANA & $1: \geq 640$ & Negative \\
Anti-dsDNA & $742 \mathrm{IU} / \mathrm{ml}$ & Negative \\
C3 & $109 \mathrm{mg} / \mathrm{dl}$ & $90-180 \mathrm{mg} / \mathrm{dl}$ \\
C4 & $<6 \mathrm{mg} / \mathrm{dl}$ & $15-40 \mathrm{mg} / \mathrm{dl}$ \\
CH50 & $94 \%$ & $75 \%-125 \%$ \\
C4A & $<0.1 \mathrm{mg} / \mathrm{dl}$ & $3.5-23 \mathrm{mg} / \mathrm{dl}$ \\
C4B & $6.6 \mathrm{mg} / \mathrm{dl}$ & $2.8-22 \mathrm{mg} / \mathrm{dl}$ \\
\hline
\end{tabular}


strongly positive (1: >640; IIF on HEP2 cells) as were anti-dsDNA antibodies (Farr assay; $742 \mathrm{IU} / \mathrm{ml}$ ).

A diagnosis was made of (idiopathic) active systemic lupus erythematosus (SLE) and the patient was treated with $1000 \mathrm{mg}$ methylprednisolone iv followed by oral prednisone $40 \mathrm{mg}$ a day with a good clinical response while proteinuria disappeared and CRP levels normalized. After stopping diclofenac transaminases normalized. After dismission prednisone was gradually tapered to $5 \mathrm{mg}$ a day and hydroxychloroquine $400 \mathrm{mg}$ a day was added.

Two weeks after admission complement C3 was 109 $\mathrm{mg} / \mathrm{dl}(90-180 \mathrm{mg} / \mathrm{dl})$ and C4 < $6 \mathrm{mg} / \mathrm{dl}(15-40 \mathrm{mg} / \mathrm{dl})$. CH50 was normal (94\%; normal values $75 \%-125 \%$ ). During follow up, levels of C3 always were normal as was CH50 whereas C4 was persistently strongly decreased $(<6 \mathrm{mg} / \mathrm{dl})$, however without signs of clinical disease activity. Anti-dsDNA became and remained negative up to 2010. In 2010 there were no signs of clinical disease activity using prednisone $5 \mathrm{mg}$ a day.

\section{Complement Assays}

The activity of the classical pathway (CH50) was determined according to Meyer [9] and expressed as a percentage of the serum pool of 30 healthy donors. The concentrations of the complement factors C3 and C4 were measured by an immunoturbidimetric assay on a Cobas Fara autoanalyser.

\section{Additional Examinations of Complement}

C4A level was below detection limit $(<0.1 \mathrm{mg} / \mathrm{dl}$; normal range 3.5 - $23 \mathrm{mg} / \mathrm{dl}$ ) and C4B level was $6.6 \mathrm{mg} / \mathrm{dl}$ (normal range $2.8-22 \mathrm{mg} / \mathrm{dl}$ ) as measured by ELISA [8]. MPLA (Multiplex Ligation-dependent Probe Amplification, 9) revealed the presence of $2 \mathrm{C} 4 \mathrm{~B}$ genes and complete absence of C4A genes.

\section{Discussion}

Our case with SLE had persistently severely depressed C4 levels during a long lasting quiescent disease stage while C3 levels were normal as was CH50. Complement assays were at first performed two weeks after admission when lupus activity had largely decreased.

In spite of the very low $\mathrm{C} 4$ concentration, $\mathrm{CH} 50$ activity was within the normal range. This indicates that sufficient functional C4 was present for complement activition by the classical pathway. Additional analyses showed no C4A, but a normal C4B level resulting in a low total C4 concentration. So, in SLE decreased levels of C4 not always implicate disease activity, in casu complement consumption.

Heterozygous and homozygous deficiencies of C4A have been reported in $40 \%-60 \%$ of SLE patients from almost all ethnic groups or races investigated (reviewed in Ref. [6]). Hence, a persistently low C4 level might be frequently misinterpreted in SLE.

It has been reported that lupus patients with homozygous C4A deficiency have other disease characteristics than heterozygous lupus patients. Petri et al for example found a reduced frequency of seizures and proteinuria in homozygous lupus patients [5]. Indeed, our patient did not have significant proteinuria nor seizures.

\section{Conclusion}

we suggest to look for inherited complement deficiencies in case of severely depressed levels of C4 in lupus patient without signs of clinical disease activity and/or normal values of C3 and CH50. When, in such a case, a C4A isotype deficiency is found, this complement component cannot be used to monitor disease activity in SLE.

\section{REFERENCES}

[1] E. J. ter Borg, G. Horst, E. J. Hummel, P. C. Limburg and C. G. M. Kallenberg, "Predictive Value of Rises in Anti-Double Strand DNA Antibody Levels for Disease Exacerbations in Systemic Lupus Erythematosus," Arthritis and Rheumatism, Vol. 33, No. 5, 1990, pp. 634643. doi:10.1002/art.1780330505

[2] W. Lloyd and P. H. Schur, "Immune Complexes, Complement and Anti-DNA in Exacerbations of Systemic Lupus Erythematosus,” Medicine, Vol. 60, No. 3, 1981, pp. 208-217. doi:10.1097/00005792-198105000-00004

[3] A. J. G. Swaak, J. Groenwold and W. Bronsveld, "Predictive Value of Complement Profiles and Anti-dsDNA in Systemic Lupus Erythematosus," Annals of the Rheumatic Diseases, Vol. 45, 1986, pp. 359-366. doi:10.1136/ard.45.5.359

[4] E. K. Chung, Y. Yang, K. L. Rupert, K. N. Jones, R. M. Rennebohm, C. A. Blanchong, et al., "Determining the One, Two, Three, or Four Long and Short Loci of Human Complement C4 in a Major Histocompatibility Complex Haplotype Encoding C4A or C4B Proteins,” American Journal of Human Genetics, Vol. 71, No. 4, 2002, pp. 810-822. doi:10.1086/342778

[5] M. P. Petri, R. W. Watson, J. A. Winkelstein and R. H. McLean, "Clinical Expression of Systemic Lupus Erythematosus in Patients with C4A Deficiency," Medicine, Vol. 72, No. 4, 1993, pp. 236-244. doi:10.1097/00005792-199307000-00003

[6] Y. Yang, E. K. Chung, B. Zhou, K. Lhotta, L. A. Hebert, D. J. Birmingham, et al., "The Intricate Role of Complement Component C4 in Human Systemic Lupus Erythematosus," Current Directions in Autoimmunity, Vol. 7: 2004, pp. 98-132. doi:10.1159/000075689

[7] N. A. Bishof, T. R. Welch and L. S. Beischel, "C4B Deficiency: A Risk Factor for Bacteraemia with Encapsulated Organisms," The Journal of Infectious Diseases, Vol. 162, No. 1, 1990, pp. 248-250. doi:10.1093/infdis/162.1.248

[8] D. Wouters, P. van Schouwenburg, A. van der Horst, M. 
de Boer, D. Schooneman, T. W. Kuijpers, et al., "HighThroughput Analysis of the C4 Polymorphism by a Combination of MLPA and Isotype-Specific ELISA's," Molecular Immunology, Vol. 46, No. 4, 2009, pp. 592-600. doi:10.1016/j.molimm.2008.07.028

[9] M. M. Meyer, “Experimental Immunochemistry,” 2nd Edition, Charles C Thomas, Springfield, 1961, pp. 133240. 